\title{
DID A BIASED JURY CONVICT PLATO'S SOCRATES?
}

\author{
Emmanuel K. Ackah, PhD \\ Department of Classics \\ University of Ghana \\ Legon, Ghana
}

\section{Abstract}

It is a matter of scholarly controversy how much of Socrates' conviction for impiety and for corrupting the youth could be blamed on Socrates' own defence, on the strength of the prosecution's argument, which has not survived, and on prejudicial pre-trial slanders against Socrates. At a point in his trial, Socrates was convinced - and he effectively told the jury this - that he has ably disposed of the charges brought against him and that if he is convicted, it would be the result of judicial bias, namely, of the enduring prejudicial pre-trial slanders against him. The burden of this paper is to examine the verifiability of Socrates' claim that a biased jury convicted him.

'That I have not committed the crime alleged in the indictment does not require much defence, gentlemen of the jury. And I think I have already said enough. However, you know well that a statement I made earlier remains true: that many are the enemies I have incurred, and this is what will lead to my conviction, if I am convicted, not the [prosecution] but the malicious slander and jealousy of the many' (Apology, 28b3-b1). ${ }^{2}$

A good number of Socratic scholars believe that Socrates was convicted because he prevaricated in his defence. Socrates himself did not believe that he lost the case because he lacked argument or words $(28 \mathrm{a} 2-\mathrm{b} 2 ; 38 \mathrm{~d}){ }^{3}$ rather, he believed that he lost because the pre-trial slanders against him were so great that he needed more time to convince the jury (37b;28a3-8; cf. 19a). Granting, therefore, 
that Socrates did not lack argument or words in his defence, my aim in this paper is to examine the verifiability of his prediction in the epigraph that his conviction would be due to pre-trial prejudices against ${ }^{\star}$ him. To achieve my aim I shall address three specific questions:
(1) Were the pre-trial slanders against Socrates prejudicial to the determination of the matter before the court?
(2) What was the extent of the slanderous publicity, namely, to what extent did the 501 or so jurors have knowledge of the slanders?
(3) If the slanders were prejudicial, did they influence the jury?
In other words, was Socrates a victim of judicial bias?

\section{Were the Pre-Trial Slanders Prejudicial to Socrates' Case?}

To determine this question we need to set out the pre-trial slanders alongside the official charges (hereafter, 'indictment') to see how or whether they relate. Socrates precedes his defence of the indictment by addressing the slanders against him. He claims that he is more afraid of the slanderers than the official accusers, because the former, mostly nameless and very many, are responsible for widespread malicious falsehoods against him ${ }^{4}$ since the childhood of most jurors (18a6-c); and also because these slanders are the very grounds of the indictment. Three times in his defence, Socrates states these slanders in the form of a sworn indictment (hosper...ten antamosian, 19b3-4). Though each statement of the slanders is only a shade different from the others, the differences deserve attention. I reproduce them here, each labelled for ease of retrospective reference:

$\mathrm{S}_{1}:$ [1] There is a clever man (sophos aner), Socrates, who [a] contemplates meteorological phenomena and investigates everything below the earth and $[\mathrm{b}]$ makes the weaker argument defeat the stronger (18b6-c1). 
$\mathrm{S}_{2}:$ [1] Socrates is a wrongdoing busybody (adikei kai periergazetai), in that he [a] inquires into things below the earth and in the sky, [b] makes the worse argument defeat the better, and [c] teaches others the same (19b4-c1).

Socrates states these slanders even more fully at $23 \mathrm{c}-\mathrm{d}$, where he claims that a number of young men, sons of the leisure class, have voluntarily attached themselves to him because they enjoy seeing other people cross-examined. Taking Socrates as their model, they try to question other people, whom they usually find pretentious. These victims of the elenchus become angry, not with themselves, but with Socrates, and they complain:

$\mathrm{S}_{3}$ : [1] Socrates is the most polluted person (miarotatos) and [c] he corrupts the youth. But if someone asks them what Socrates practices (poion) and teaches (didaskon), they cannot tell; but in order that they may not appear to be at a loss, they repeat the ready-made accusations that are used against all philosophers, that he [a] [investigates and [c] teaches]] things up in the clouds and under the earth, [a*] he does not believe in gods, and [b] he makes the worse appear the better reason.

Each of these slanders, $\mathrm{S}_{1} \mathrm{~S}_{2} \mathrm{~S}_{3}$, reveals a tripartite structure. First, each begins with an introductory clause of criminal designation [1]: Socrates is 'a clever man' (sophos aner), 'a wrongdoing busybody' (adikei kai periergazetai), and 'a most polluted person' (miarotatos). It is clear that, in context, sophos has a pejorative connotation; hence, the gloss 'clever' rather than the literal 'wise'. This gloss is confirmed both at Apology 23a1-2 where Socrates links "sophos" to the many slanders (pollas diabolas), which are the result of popular misperception of his elenctic philosophy, and at Euthyphro 3c7-9 where Socrates tells Euthyphro that Athenians do not worry much about anyone being clever (deinon) provided he does not teach his cleverness (sophias). Socrates thus understands his nickname 
'sophos' to connote 'a socially dangerous man'. The designation 'adikei kai periergazetai' implies that Socrates is a social pest, while 'miarotatos' suggests that Socrates is a social pollutant. These last two designations are largely variants of the first designation, or so I shall take them.

The second structural part of the slanders, namely, the statement immediately following the introductory clause, imputes to Socrates certain potentially offensive or dangerous beliefs and/ or practices: that $\left[\mathrm{a}^{*}\right]$ Socrates does not believe ${ }_{6}$ gods, and that $[\mathrm{a}]$ he practices natural science and [b] eristicism. ${ }^{6}$ Natural science was potentially dangerous for society because of the popular belief that natural scientists were atheistic (18b7-c4). So [a] collapses into $\left[\mathrm{a}^{*}\right]$. And eristicism, the stock in trade of the Sophists' education, was potentially dangerous for society because it is an argumentative method for producing antilogies of every belief. When applied to traditional religious and moral beliefs, eristicism entails scepticism about these beliefs. Besides, it has a shaming effect on those whose beliefs are subjected to its application. Eristicism can be employed as a tool for refuting opposing theses. Therefore, it resembles the Socratic elenchus, whose application typically results in the logical refutation of respondents' moral theses. Consequently, the practice of elenchus at the hands of insensitive youths could become a sport for shaming elders by showing the inconsistency, falsity or, indeed, the absurdity in their beliefs.

In the third structural part of the slanders, the potentially offensive beliefs and practices of the second part are shown to have [c] actually caused some social damage: Socrates is perceived to have actually corrupted the youth by teaching (didaskon) them atheistic natural science and eristicism. The second and third structural parts of the slanders together give rise to or explain the first structural part, that is, the introductory criminal designation or the various nicknames Socrates has earned. From the foregoing, we can reconstruct the slanders $\left(\mathrm{S}_{1}, \mathrm{~S}_{2}, \mathrm{~S}_{3}\right)$ by putting them together 
as follows:

$\mathrm{S}_{4}$ : [1] Socrates is a socially dangerous man, in that he believes in and practices [a*] atheism and [b] eristicism, and he [c] corrupts the youth by teaching them to follow his example.

Let us now look at the indictment (official charges) against Socrates. Allegedly preserved in its original form in the work of the third century AD writer Diogenes Laertius, it reads as follows:

[1] Socrates does wrong (adikei), in that [a*] (i) he does not acknowledge the gods of the State but (de) (ii) other new divine things he has introduced; and [c] he also does wrong by corrupting the youth.

It is controversial whether or not the conjunction "de" introduces another charge." Which way one reads it makes no difference to my argument. Note, however, that the tripartite structure of the slanders is present in the indictment too. First is the introductory clause [1], which here describes Socrates simply as a 'wrongdoer': 'Socrates adikei'. This contrasts sharply with the strongly condemnatory introductory clauses of the slanders. The second part of the indictment, the clause immediately following the introductory clause, is a statement imputing socially dangerous beliefs to Socrates, namely, [a*] (i) and (ii). The prosecution interpreted these beliefs to mean that Socrates is an atheist (26bc). The effect of the prosecution's interpretation is that the second structural part of the indictment is substantially the same as onehalf of the second structural part of the slanders, namely, $\left[\mathrm{a}^{*}\right]$ of $\mathrm{S}_{4}$, with the other half, (b) of $\mathrm{S}_{4}$, to spare.

Finally, the third part of the indictment, [c], is a statement alleging that Socrates has actually caused social damage: that he corrupts the youth. The means by which Socrates causes this damage - teaching - is not specified in the indictment, as it is in the slanders. However, during Socrates' defence against the indictment, he asks 
the prosecution (26c): 'Do you say that I corrupt the youth by teaching them not to believe in the gods of the State but in other new divine things?' The prosecution emphatically answers in the affirmative. Altogether, then, the slanders is, in form and substance, similar to the indictment, the former imputing greater reprehensible conduct to Socrates on account of (b).

Consequently, because the indictment more or less reproduces the slanders in form and substance, and because the slanders are chronologically prior to the indictment, Socrates was absolutely right in saying that the slanders were the very grounds of the indictment against him, and that the slanders were highly prejudicial to his case and could lead to his conviction. Our next task is to determine the extent of the slanderous publicity.

\section{Extent of the Slanderous Publicity against Socrates}

Socrates refers to the slanders against him as having been perpetrated by 'a great many people for a great many years' (18b1-2), starting at the time 'when so many of [the jurors] were children' (18b5) and 'at their most impressionable age' (18c6-7). Of these diverse, numerous, and largely anonymous slanderers, Socrates readily remembers Aristophanes, who portrayed Socrates in the Clouds mainly as one who corrupts the youth by teaching atheistic natural science and eristicism.

Aristophanes' Clouds was performed in $423 \mathrm{BC}$ at the City Dionysia. A revised version was put in circulation by or after 416 BC. At the same festival in the same year, two other comedies equally adverse to the Socratic circle were performed. ${ }^{15}$ The fourth century theatre held between 14,000 and 17,000 spectators, and it is likely that the late fifth century audience was roughly of this size too. Even if a total of 10,000 attended, this would include a very high percentage of Athenian citizens, whose population after the plague of $429 \mathrm{BC}$ and throughout the Peloponnesian War hovered around 20,000 to $30,000{ }^{17}$ There is, however, some controversy over the composition of Athenian festival audiences; ${ }^{18}$ but in all probability, 
most spectators would be adult male Athenian residents, perhaps with a scattering of slaves and women. Since only a citizen 30 years old or more qualified for jury service in Athens' democratic State, the youngest of the jurors trying Socrates in $399 \mathrm{BC}$ would be six or seven years old when the Clouds was performed.

Aristophanes caricatured Socrates as typifying the atheistic natural scientist and the eristic sophist, pioneers of a newfangled education that was, in Aristophanes' view, atheistic and socially harmful. It is very likely that this Aristophanic view of Socrates was also the popular view: Aristophanes would want to win the first prize and would most unlikely put on stage a play whose theme and chief character his audience are not familiar with. But if this were so, the fact that Socrates continued to practice his elenctic philosophy for the next twenty-four years after the performance and subsequent sale of the Clouds in the open market would tend to perpetuate the adverse popular image of Socrates throughout the maturing years of the youngest potential juror in 399 BC. Could we, then, conclude that the jurors who tried Socrates actually knew this adverse publicity about Socrates? Before answering this question, we must remind ourselves of the following well-known facts about Athenian society.

Greek cities were generally small territorially. Cosmopolitan ones, such as Athens, were usually populous. Communality in Athens was reinforced by a number of social institutional factors: the agora, which was the hub of economic, social, and political activity, invited daily meeting of several people; the gymnasia were daily resorts for the youths and adults; the symposia of the middle/upper class were recurring occasions for conviviality and for discussion of various issues; and multiple forms and number of associations, from welfare to funerary clubs, provided sundry other fora for association.

These varied social institutions and associations were highly conducive to the rapid and widespread dissemination of information in Athens, so that any persistent adverse opinion about someone as 
famous as Socrates ${ }^{21}$ could have a publicity effect equal to that of a mass circulating electronic or other media in a modern nation. Thus, it would be fair to say that in $399 \mathrm{BC}$ every potential juror was aware, to a degree, of an image of Socrates that was highly prejudicial to the case in court. It must be noted, however, that one could be aware of prejudicial matters against someone without being biased against him/her. Thus modern-day jurors are, as a matter of jurisprudential requirement, supposed to come from the neighbourhood where the matter in question took place or where the parties come from, because neighbours, more than the presiding judge, often do have first-hand knowledge of the facts in issue, including, where relevant, knowledge of the character of the parties and their witnesses. Hence, a juror's knowledge of pre-trial prejudicial matters against the accused does not in itself constitute judicial bias against the accused, though recent practice in some jurisdictions tends to exclude jurors who have even a smattering of pre-trial knowledge of the case to be tried. 22

That brings me to my last question: if every juror sitting in Socrates' case had knowledge of the prejudicial pre-trial slanders against Socrates, was his decision influenced by such knowledge? In answering this question in the next section, I will also be addressing the following preliminary issues: what is judicial bias? And how do we test for a juror's bias? Did the Athenian legal system contain mechanisms for detecting and preventing biased jurors from sitting? If not, how do we verify that Socrates was or was not a victim of judicial bias?

\section{Was Socrates a Victim of Judicial Bias?}

A basic rule of the adversarial system of adjudication, even as it applied in ancient $A$ thens, is that a verdict is to be based on evidence adduced and argument given in open court (cf. Apology 35c-d). Judicial bias occurs where a judgment or verdict is based, not on the evidence and/or argument given in court, but on extra-judicial considerations. 
To prevent judicial bias, the modern practice is to test potential jurors for bias before hearing begins. The prevailing test, laid down by Chief Justice Marshall in the 1807 treason trial of Aaron Barr, is for the trial judge to elicit a potential juror's attitude toward the matter to be tried in order to determine whether his/her mind is relatively open to or closed against the testimony that may be offered in court in opposition to his/her opinion about the accused. In other words, a juror is impartial who, at the time of the trial, is indifferent as to the guilt or innocence of the accused.

In some jurisdictions, a party could challenge the panel of selected jurors in a number of ways: the party could challenge for cause, that is, make a request to a judge that a certain prospective juror not be allowed to be a member of the jury because of a specified reason or cause; the party could also make a peremptory challenge, in which case he need not show any reason for objection to the prospective juror sitting; or, the party could challenge the array, that is, challenge the whole panel of jurors on the ground that the form or manner of empanelling the jury was improper or illegal; for example, that it was tainted by class, racial or other prejudicial considerations.

Were there procedural means for detecting and for preventing biased jurors from sitting in the Athenian jury courts? The Athenian judicial system did not have a Marshallian test, nor would such a test have been practicable given the large number of jurors sitting on a case. The Athenian judicial system also did not have the various forms of jury challenges. However, it did have some means of preventing judicial bias. First, jurors took an oath at the beginning of the year, in a solemn ceremony, to vote according to the laws and decrees of the Athenian people, to consider only the matter of the charge, to hear both sides impartially, and where there was no law covering the case, to vote according to their most honest judgment. The oath closed with an invocation of the gods - Zeus, Poseidon, and Demeter - to punish violators by the utter destruction of themselves and their families and to reward richly those who kept 
their oaths. Evidently, this is a very powerful oath. ${ }^{24}$ Second, the court was empanelled by anything from two hundred to more than a thousand jurors; ${ }^{25}$ and it is extremely difficult, if at all possible, to influence this large number. Third, the jurors were selected by lot, i.e., randomly, from an annual jury register of 6,00026 immediately before the opening of the case. So that a potential juror could not choose, and could not know until the last minute, which of the many cases pending in a day he would sit on. This procedure of selection would overcome the modern-day possibility of convenors or judges influencing the selection of jurors. Yet the Athenian selection procedure was not foolproof: in the absence of a Marshallian test and challenges to jurors, there was always the possibility that biased jurors could be selected accidentally.

Suppose, then, that biased jurors were accidentally selected. What were the chances that Socrates left the court a victim of judicial bias? Every case had to be determined at a sitting in a day, and the verdict was voted by secret ballot immediately after the parties had closed their cases and while the evidence and argument of the parties were still fresh in the minds of the jurors. Thus, there was no recess for collective deliberation among jurors on the evidence and argument presented and no judge whose presiding duty was to sum up the relevant facts and direct the jury on the relevant law. Arguably, then, the absence of collective deliberation after parties have closed their cases would serve to control the spread of any biases some jurors may harbour. However, such control could be neutralised by the fact that during proceedings jurors took liberties with the rules to murmur or whisper to each other. Yet, even if we assume that those who murmured or whispered to others were biased against Socrates, we need further evidence to justify an inference to the conclusion that the murmurs or whispers, allowing any number and frequency of occurrence, had enough persuasive content or force to influence unbiased jurors. It is, therefore, reasonable to suppose that, on the balance of probabilities, biased jurors would not significantly affect unbiased ones during proceedings. Consequently, 
we still face the original question: suppose that biased jurors were accidentally selected, what were the chances that Socrates left the court a victim of judicial bias.

Socrates had four chances, though only one of them was formal and, indeed, required by legal procedure. The first, and this is the only formal chance, was to convince the jury by evidence and argument that he was innocent of the charges. Socrates claims that he did his best, and we began by accepting his claim. Socrates' second chance was to remind the jury of their oath; indeed, Socrates did remind the jurors of their oath at the close of his case: 'it is not a juror's duty to give justice as a favour, but to judge according to law, and this he has sworn to do' (35c3-4). However, what effect the oath could have on a biased juror depended on a number of factors, not least of which would be the juror's religiosity; but this is very difficult, if at all possible, to measure in a society like Athens, where increasing rationalism continually dented the frontiers of religion, superstition and myth. Thus, we have no means of calibrating the weight of the oath on each juror's mind. The third and fourth chances available to Socrates lay with the laxity in the rules of evidence, enabling a party to plead extra-legal considerations. ${ }^{28}$ In this respect, character pleading is the third of the chances available to a party to counter jury bias against him. Though to plead one's character may be inappropriate in all criminal cases, it is certainly appropriate in an indictment for moral corruption and for impiety, since such an indictment calls into judicial question the beliefs, practices and character of the accused. Charged with impiety and with corrupting the youth, Socrates appropriately pleaded his character, though it did not lead to his acquittal. Another extra-legal chance, the fourth chance available to Socrates to counter juror bias, was to plead for mercy and/or even to flatter the jury. Socrates, however, expressly refused to resort to this form of pleading on the ground that it would pervert legality and justice (Apology 35). Socrates' conscientious refusal to resort to this type of pleading is certainly praiseworthy, but arguably a missed 
opportunity to neutralise any adverse biases that may have persisted in the mind of any juror.

\section{Conclusions}

We found that, before his trial Socrates had a public image that was highly prejudicial to the case before the court. We also found the publicity of this prejudice so extensive that every potential juror in 399 BC could be deemed to have knowledge of it. The critical question was whether, before proceedings began the individual juror was indifferent as to whether or not Socrates was guilty of the charge(s) brought against him. To answer that question we needed to know whether these prejudices had a strong or weak hold on the minds of the jurors: if strong, they would lead to juror bias, if weak, they would not. Though no individual or party could influence the selection of jurors for a court, Athenian legal procedure had no practicable method for detecting bias among prospective jurors of several hundred per court. But if biased jurors were accidentally selected, the party who is a potential victim of bias had four chances to counter the bias.

First, the only formal chance required the party (potential victim of bias) to present a strong case by argument and evidence. Socrates claims that he argued well in court. Second, the party could remind the jury of their oath to judge the matter strictly according to law, where a law covered the case. But the jury oath, though powerful, depended for its effect on the religiosity of the individual juror, a factor we can hardly determine. At any rate, Socrates reminded the jury of their oath. Third, the party could plead his character. Socrates pleaded his character in court, but here too we have no means of determining its effect on the jurors. We do know, however, that Socrates was convicted despite pleading his character. Finally, the party could plead for mercy and/or flatter the jury. Socrates refused to do this. Though this pleading is perverse, Socrates' refusal to resort to it is arguably a missed opportunity to win sympathy and favour. 
In the end, we have no means of verifying whether the verdict of the jurors was reached solely on the basis of the competing claims of prosecution and defence in court, or partly or wholly on the basis of pre-trial prejudicial biases against Socrates. Thus, it is impossible to verify Socrates' claim that his conviction is the result of judicial bias rather than the result of the prosecution's argument or a failure of defence.

\section{Reference and Notes}

1 'Socrates' in this paper means the Socrates of Plato's Apology (or Defence of Socrates).

${ }^{2}$ The Greek text is Loeb's (1914), with English translation by H.N. Fowler. The translations in this paper are my adaptation of Fowler's and G. M. A Grube's in Plato: Complete Works (ed.) John M Cooper (1997), Indianapolis/Cambridge.

${ }^{3}$ All references will be to Plato's Apology, unless otherwise indicated.

4 'Malicious falsehood' is contained in 'pseude kategoremena' at 18a6-7 and 'phthonoi kai diabole' at 18d2. Cf. 19a2, $19 \mathrm{~b} 2$.

Since 'being a busybody' by itself was not a crime, it is better to read the 'kai' epexegetically.

${ }^{6}$ In Plutarch's Alcibiades 22.3 the indictment of impiety brought by Thessalus against Alcibiades contains the introductory clause 'adikein peri to theo ten Demetran kai ten Koren,' followed by the alleged offences.

7Cf. Republic 538c6-539b; Aristophanes' Clouds 1019-1021, where Just Logic accuses Unjust Logic of inducing the belief that everything shameful is fine and the fine shameful. See further C.D.C Reeve [1989] 164-165, Socrates in the Apology, Indianapolis/ Cambridge.

${ }^{8}$ Cf. R.E. Allen [1970] 47, Plato's Euthyphro and the Earlier Theory of Forms. London: 'To an observer, elenchus would have appeared perhaps equal parts banter and hair-splitting. To a respondent, perhaps, a self-important politician cornered in the Agora, it must 
have seemed mainly to consist in subtle and unanswerable insult'. 9 As framed, the slander of eristic practice must be understood against the background of its otherwise implicit complex effects, including its potential for undermining traditional beliefs and values and for shaming men reputed or claiming to be wise.

${ }^{10}$ Diogenes Laertius 2.40. Diogenes claims to be citing verbatim from a Roman writer called Favorinus, who in turn claims to have seen a copy of the indictment in the Metroôn in the Agora, which functioned as a public archive. Cf. Apology 24b6-9, where Socrates states the indictment in indirect speech as follows: [1] 'It says that Socrates does wrong (adikein), in that he [c] corrupts the youth and $\left[a^{*}\right](i)$ does not acknowledge the gods the state acknowledges but (de)(ii) other new divine things'. The only important difference with Diogenes' version seems to be the order of the charges.

The prevailing reading is that it contains another charge, so that there are three charges in all. For those who see only two charges, see e.g., James Beckman [1979] 55, The Religious Dimension of Socrates' Thought, Waterloo.

${ }^{12}$ We do not need to quibble about the fact that the $\left[\mathrm{a}^{*}\right]$ part of the indictment is inherently contradictory, as Socrates pointed out in his defence. It is important that the one who framed it, the prosecution, understands it to constitute an accusation of atheism. When Socrates, attending preliminary proceedings at the chief magistrate's office meets Euthyphro, he relates, and must therefore have understood then, that he has been indicted for corrupting the youth by teaching them not to believe in the gods of the city but other new divine things (Euthyphro 2c-3b, 3c6-d8).

${ }_{15}^{14}$ Cf. Reeve [1989] 17-18.

${ }^{15}$ McLeish, Kenneth [1980] 36, The Theatre of Aristophanes, Gt. Britain.

${ }_{17}^{16}$ McLeish [1980] 35.

${ }^{17}$ Cf. Josia Ober [1989] 127-128, Mass and Elite in Democratic Athens, Princeton.

${ }^{18}$ See Pickard-Cambridge (1962), The Dramatic Festivals of Athens, 
$2_{19}^{\text {nd }}$ edn., Oxford.

Cary, M and Haarhoff, T.J. [1961] 148-160, Life and Thought in the Greek and Roman World, London.

${ }^{20}$ See Murray, Oswyn [1986] 204-233, 'Life and Society in Classical Times' in The Oxford History of Classical World, Oxford.

${ }^{21}$ Socrates was popular in Athens (Apology 34e-35e1) and beyond. Though he did not travel outside Athens except on military missions (Crito 52b), he attracted numerous disciples both in Athens (Apology 33d-34a) and beyond. Cf. Phaedo 59b-c. In Athens Socrates spoke, and was known, to many people, different in age (Apology 30a), wealth, and profession (Apology 21b-24b, Republic 1); and he spoke to them everywhere: at the agora (Apology 17c9); Symposia (cf. Plato's Symposium), Palaestrae (Charmides 153a-154a), Gymnasia (Euthyphro 2a1-2, Lysis 203a, Euthydemus 271a).

See, for e.g., Christopher Berry Gray [1999] 462, ed., The Philosophy of Law: An Encyclopedia, New York/London.

${ }^{23}$ See Joseph M. Hasset [1984] 290-296, 'Prejudicial Publicity and a Jury's Pretrial Knowledge' in Readings in the Philosophy of Law, ed. John Arthur and William H Shaw.

${ }^{24}$ The veracity of the oath, whose source is Demosthenes 24.14951 , has been debated, but there is no powerful reason for rejecting it. See also the comments of R. J. Bonner and Getrude Smith [1968] $153 \mathrm{ff}$., The Administration of Justice from Homer to Aristotle, New York, Vol. 11 .

Any citizen who was 30 years old or more and was not in debt or under atimia qualified for jury service. Atimia involved the temporary suspension of a citizen's rights until the wrong which was the ground of such suspension was discharged either by the effluxion of time or by specific performance of some obligation.

${ }^{26}$ In his defence against the charge of violating the decree prohibiting him from attending religious festivals (Andokides 1.2, 1.111; Demosthenes 24.105), Andokides alludes to the case in which his father prosecuted Speussipus for illegally informing about him regarding the parody of the mysteries, and he says that the case 
came before a panel of 6,000 jurors! This is the total number of people listed for jury service in the year-perhaps the only instance, if it is true, of the whole body sitting as a single court.

${ }^{27}$ Indeed, a party was required to produce the relevant law in support of his case. But the role of the presiding officer was merely to see that the contestants observed the rules.

${ }^{28}$ The rules of evidence were lax in many other ways. For example, hearsay was by law excluded in evidence, except to report what had been said by a person now dead. (See McDowell [1978 ] 243, The Law of Classical Athens, Ithaca). In practice, hearsay may have been tolerated, as the first half of Socrates' defence was against what he heard others say about him.

${ }^{29}$ T. M. Cary \& T. J. Haarhoff [1961] 39; Apology 34b6-35b8; Glenn Morrow [1960] 241-296, Plato 's Cretan City, Princeton.

${ }^{30}$ It may well be speculated that the small number of votes that tilted the scale toward Socrates' conviction represents those whose biases could not be disabused by his legal (that is, without the extralegal) defence against the charges. 